\title{
VOLD, EVOLUSJON OG NYE MILJØFAKTORER
}

\author{
Af CAND. Scient. Iver Mysterud og DR. Philos Dag Viljen Poleszynski
}

\begin{abstract}
We are far from a unified model to explain the phenomenon of violence. A focus on evolution, however, could unify research emphasizing psychosocial factors and genetic/biochemical/physiological variables as explanations for violence. Even if evolutionary psychology has great potential for improving the understanding of human behaviour, it is still hampered by weaknesses. Several novel environmental factors may compromise the design which has been useful for human survival and reproduction in the past, and which has been inherited from our ancestors. Intake of nutrient deficient foods giving rise to reactive hypoglycemia (low blood sugar), the existence of food allergy/intolerance, and the widespread exposure to novel toxins (heavy metals, synthetics) may contribute to violent behaviour *
\end{abstract}

\section{Innledning}

Vold er et samfunnsproblem som opprører og engasjerer. Det vies mye oppmerksomhet både i massemedier og i ulike faglige fora. På verdensbasis har et stort antall forskere i flere tiår studert forskjellige sider ved voldsatferd og bakgrunnen for den. Derfor skulle man kanskje anta at forskere hadde kommet fram til enighet om en del hovedprinsipper og grunnteorier for å forklare slik atferd. Dette er imidlertid ikke tilfellet. Hvis man studerer en del av den litteraturen som finnes om vold, oppdager man nokså raskt at det ikke finnes noen enhetlig teori som forbinder de ulike tilnærmelsene. For eksempel vektlegger noen forskere psykososiale miljøfaktorer som årsaker til vold, mens andre mener genetiske, biokjemiske eller fysiologiske variabler kan si noe kausalt om slik atferd. Disse forskerne ser ut til å leve i forskjellige verdener. Dette er uheldig.

Vi viser i denne artikkelen på hvilken måte et evolusjonsperspektiv kan forene tilsynelatende ulike forskningstradisjoner. Selv om evolusjonspsykologien har store muligheter for å gi en bedre forståelse av menneskets atferd, har også den per i dag svakheter. Vi argumenterer for at en rekke nye miljøfaktorer kan stikke kjepper i hjulene på den utformingen som har vært hensiktsmessig for å overleve og formere seg i fortiden, og som vi har arvet fra våre forgjengere. Nye miljøfaktorer som inntak av næringsfattig mat, som blant annet kan føre til reaktiv hypoglykemi (lavt blodsukker), forekomsten av matvareallergi/-intoleranse og en allmenn eksponering for nye miljøgifter (tungmetaller, syntetiske stoffer)

* Title in English: Violence, Evolution and Novel Environmental Factors. Original in Norwegian. 
kan bidra til voldelig atferd. Vi mener det er vesentlig at samfunnet begynner å diskutere slike problemstillinger om vi skal kunne møte mye av den volden vi ser i samfunnet på effektiv måte.

\section{Samfunnsvitenskapenes standardmodell}

I samfunnsdebatten er det slående hvordan noen få tilnærminger dominerer. Alt annet overskygges i dag av tradisjonelle samfunnsvitenskapelige forståelser som utelukkende fokuserer på det psykososiale miljøets betydning for voldelig og aggressiv atferd. Typiske eksempler på resonnementer kan være utsagn av typen: "Ikke rart han er voldelig, han som har hatt en slik oppvekst" eller "Det er fullt forståelig at disse personene blir aggressive, siden de lever under så kummerlige livsforhold."

Satt på spissen kan sosiologiske og psykososiale modeller karakteriseres slik: Hvis en gitt atferd viser seg under bestemte kulturbetingelser, har den ikke noe med arv å gjøre. Dypkulturelle og kulturelle faktorer, ideologier, sosioøkonomiske og psykososiale forhold $\mathrm{i}$ en persons miljø kan fullt ut forklare bakgrunnen for menneskets sosiale atferd. Denne måten å resonnere på er omtalt som "samfunnsvitenskapenes standardmodell" (Tooby \& Cosmides 1992). Forenklet kan man si at standardmodellen setter et grunnleggende skille mellom biologiske og kulturelle faktorer. Biologien utruster mennesket med fem sanser, noen få drifter som sult og frykt og en generell læringsevne. Ifølge standardmodellens tilhengere - som er omtalt som "psykologisk korrekte" av Pinker (Pinker 1997) og "biofobe" av Daly og Wilson (Daly \& Wilson 1988) - har biologisk evolusjon blitt satt ut av kraft eller blitt overskygget av samfunnsmessige endringer ("kulturell evolusjon"). Kulturen oppfattes som en selvstendig enhet som gjennomfører et ønske om å videreføre seg selv ved krav om å innfri forventninger og oppfylle roller, hvilket kan variere vilkårlig fra samfunn til samfunn. Biologi oppfattes her som like viktig som kultur når det gjelder å sette grenser for atferd, og all atferd er en blanding av biologi og kultur. Dette synet på menneskenaturen ligger implisitt $i$ behaviorismen og deler av antropologien som kulturrelativismen. For å få etablert det evolusjonspsykologiske synet på menneskenaturen (se senere), har det vært sentralt å vise at standardmodellen ikke er holdbar som eneste forklaringsmodell (se Tooby \& Cosmides 1992).

I faglitteraturen om vold eksisterer imidlertid forklaringer med bakgrunnen i standardmodellen side om side med forskning som vektlegger ulike "biologiske" forklaringer basert på kjemi, biokjemi, genetikk, nevroanatomi, nevrofysiologi og fysiologi. Enkelte av disse "biologiske" forklaringsmodellene har fătt vind i seilene de siste årene, mens andre fortsatt er neglisjert i samfunnsdebatten. "Biologiske" forklaringsvariabler for atferd fokuserer ofte på underliggende hjernekjemi. Er den annerledes hos noen med en gitt atferdstendens eller mental lidelse? Å få utviklet "en pille for alt som er ille"-mentaliteten er typisk for resonnering basert på slik forskning. Den utbredte bruken av serotoninreopp- 
takshemmere er et dagsaktuelt eksempel på at en slik strategi kan være skadelig, både fordi den ikke går til kilden (årsaken) og fordi slike medikamenter synes å være forbundet med uakseptable bivirkninger (Glenmullen 2000).

\section{Evolusjonspsykologi}

Den siste tiårsperioden har det vokst fram en forskningsretning med potensial for å binde samfunnsbaserte og biologiske tilnæringer sammen i en felles analyseramme. Vi tenker her på den såkalte evolusjonspsykologien som er anvendelse av sentrale prinsipper fra evolusjonsbiologi på psykologiske problemstillinger. Evolusjonspsykologien omtales av enkelte som et paradigme eller en metateori som kan forene de viktigste retningene innen psykologien (Buss 1995). Sentralt for evolusjonspsykologien er et fokus på menneskets fortid der våre forgjengere i økende grad ble tilpasset ulike miljøfaktorer, dels det fysisk-kjemiske miljøet og dels det levende eller biologiske miljøet. Fordi det biologiske miljøet omfatter alt fra bakterier og virus til andre mennesker, er psykososiale miljøfaktorer derfor en naturlig del av det biologiske miljøet.

Evolusjonspsykologien fokuser på hvordan vi i hovedtrekk er utformet for å takle de utfordringer - farer og muligheter - våre forgjengere sto overfor i fortidsmiljøet. Dette dreier seg for eksempel om hvordan organismen er utformet for å unngå eller bekjempe sykdom. Det handler om hvordan mennesket fikk utviklet et sanseapparat som var hensiktsmessig for å få i seg riktig og nok mat (f.eks. en smakssans som sier at "søtt er godt", siden modne og næringsrike frukter er søte, eller en luktesans som varsler oss om at bedervet mat er farlig). Det fokuseres også på vårt fleksible atferdsrepertoar som sikrer at man ikke blir lurt av andre og selv blir i stand til å få tilgang til og holde på sosiale ressurser (slik som for eksempel seksualpartnere, alliansepartnere og venner). I hovedsporet av dagens evolusjonspsykologi er det også antatt at det ikke har vært nok tid - altså tilstrekkelig antall generasjoner - til at mennesket har endret seg i vesentlig grad i grunnutforming - verken anatomisk, fysiologisk eller atferdsmessig - siden våre forgjengere ble bofaste og begynte å dyrke jorda for ca. 10000 år siden. Dette er et premiss som er kritisert (Wilson 1994), noe vi imidlertid ikke skal forfølge her.

Evolusjonspsykologien søker å forstå i hvilken grad arv kan være en forutsetning for organismens mentale utrustning (sinnet) og hvordan miljøet i samvirke med sinnet frambringer atferd. En slik modell er ikke ny i psykologien, men evolusjonspsykologene reiser i tillegg en rekke hypoteser om hvordan sinnet er utformet gjennom lange tidsrom i fortiden der våre forgjengere levde som jegere og sankere. De utfordringene steinaldermenneskene møtte i sine bestrebelser på å overleve og formere seg, kan ha vært avgjørende for formen på sinnet. I en artikkel om vold er det av interesse å diskutere hvorvidt evolusjonspsykologien kan forene både psykososiale og biokjemisk orienterte tilnærmingsmåter for å forklare på vold. 


\section{Serotonin og vold}

En biologisk markør for voldelig atferd og aggresjon ser ut til å være lavt nivå av signalstoffet serotonin i hjernen (Masters \& McGuire 1994). Dette er observert både hos barn som torturerer dyr og barn som er spesielt fiendtlige overfor sine mødre. Imidlertid er det ikke klart i hvilken grad serotonin per se påvirker aggresjon eller bare påvirker impulskontroll, ettersom lavt serotoninnivå også synes å korrelere med impulsive ildspåsettelser (Linnoila et al. 1994), med selvmord og kanskje selvmordsforsøk utført med voldelige metoder (Stein \& Stanley 1994). Med et psykososialt utgangspunkt ville man for eksempel forvente at voldelig atferd var en naturlig reaksjon fra mennesker som lever i fattige eller undertrykkende livsforhold. I så fall ville ikke voldelig atferd være et avvik eller patologisk. En evolusjonspsykolog ville være opptatt av at både gener og signalstoffer som serotonin er en gyldig vei for å forklare menneskets atferd, men ville samtidig påpeke at for eksempel vold i fattige strøk i en storby er en "naturlig" reaksjon på et spesielt sosialt miljø. Evolusjonært kan man hevde at menneskesinnet er utformet for å justere seg i forhold til det sosiale livsmiljøet man til enhver tid befinner seg i. Sinnets funksjoner antas å være felles for alle mennesker, men utfallene vil være avhengig av miljøet.

Et fokus på sosialt miljø er forenlig med et fokus på biokjemiske faktorer. En rekke eksperimentelle studier av andre primater har vist at serotoninnivået påvirkes av sosial status (Raleigh \& McGuire 1994). Dette gjelder særlig hanner, noe det finnes evolusjonære forklaringer for. Jo høyere status en hann har, desto høyere serotoninnivå. Serotoninnivået øker som et svar på faktorer i det sosiale miljøet. Hvis en dominerende primathann plutselig mister sin sosiale status, vil serotoninnivået synke.

En liknende mekanisme kunne forklare at det for eksempel er mer aggresjon og vold blant fattige og undertrykte i ghettoer i storbyer. Faktorer i det sosiale miljøet hos disse lavstatusindividene med dårlige framtidsutsikter oppfattes av deres sinn, hvilket igjen på en eller annen måte påvirker at serotoninnivået blir lavere, noe som igjen gjør det mer sannsynlig at individet reagerer aggressivt $\mathrm{i}$ omgang med andre mennesker. Dette skjer selvfølgelig ubevisst, for ifølge evolusjonspsykologiske hypoteser ser mennesket ut til å være utformet slik gjennom naturlig utvalg. Grunnen er at voldelig og aggressiv atferd kan ha medvirket til økt overlevelse og reproduksjon for de av våre forgjengere som har hatt lav sosial status og levd med dårlige framtidsutsikter. På denne måten kan slik atferd oppfattes som en tilpasning til spesielle miljøforhold (Daly \& Wilson 1994).

\section{Evolusjonspsykologi og vold}

I tillegg til partnervalg er vold og aggresjon ett av de temaene som har fått størst oppmerksomhet i evolusjonspsykologien. Dette skyldes blant annet at to av pionerene i evolusjonspsykologi - det kanadiske forskerparet Martin Daly og 
Margo Wilson - har arbeidet mye med disse temaene. Deres bok Homicide (Daly \& Wilson 1988) er av evolusjonspsykologiens klassikere. En oversikt over slike tilnærmelser til vold er for omfattende til at vi kan gå i detalj om dem her.

Vi skal imidlertid påpeke at vold og aggresjon ikke oppfattes som enhetlige fenomener fra et evolusjonspsykologisk perspektiv. Dette representerer heller en samling strategier som er til stede under helt spesifikke forhold. Mekanismene som ligger til grunn for aggresjon, har av den grunn sett dagens lys som løsninger (om de er aldri så frastøtende) på en rekke atskilte problemer som var viktige for at våre forgjengere kunne overleve og formere seg (såkalte adaptive problemer). Dette dreier seg for eksempel om å fă tilgang til ressurser, konkurranse med andre av samme kjønn, det å få status og makt i sosiale hierarkier og å holde på partnere (Buss \& Shackelford 1997).

Et slikt perspektiv forutsier på teoretisk grunnlag variasjon i aggresjon mellom kjønn, fra person til person, i løpet av livet og på tvers av kulturer. Evolusjonpsykologien er interaksjonistisk i ekte forstand. Den spesifiserer en rekke kausale forhold der det er sannsynlig at spesielle trekk ved utøveren, offeret, den sosiale sammenhengen og det adaptive problemet, utløser aggresjon som en strategisk løsning.

\section{Begrensninger ved evolusjonspsykologien}

Et evolusjonspsykologisk perspektiv på aggresjon hos mennesket har mange begrensninger. For eksempel kan det ikke forklare hvorfor én mann banker opp sin partner som har vært utro, en annen dreper partneren og en tredje drikker seg full. Fra vår egen kulturkrets kan vi tenke oss en fjerde person som verken tyr til vold eller alkohol, men tar seg noen dager fri i ensomhet på fjellet. Evolusjonspsykologien kan per i dag heller ikke forklare hvorfor menn i noen kulturer trenger å bruke vold for å få status, mens denne typen aggresjon i andre kulturer fører til ugjendrivelig skade på egen status.

Evolusjonspsykologien kommer per i dag til kort når det gjelder å gjøre rede for variasjon i voldelig og aggressiv atferd mellom og innenfor ulike kulturer. En årsak til dette kan ligge i dens manglende fokus på resultater fra forskning som undersøker effekten av ernæring og ulike former for miljøforurensning på menneskets atferd. Dette er derfor en begrensning ved både evolusjonspsykologiske studier og forskning med bakgrunn i "samfunnsvitenskapenes standardmodell". Mennesket lever i dag i et miljø som på en rekke vesentlige punkter er annerledes enn det var da mennesket fikk sin utforming i evolusjonsprosessen. I det følgende vil vi komme inn på noen av de nye miljøfaktorene som kan påvirke mennesket og dets atferd.

\section{Evolusjon og feilernæring}

Evolusjonsmedisin er det siste tiåret blitt et fagfelt som er i stand til å gi gode hypoteser eller forklaringer på en rekke somatiske og psykiske lidelser i vår tid. 
En av de mest slående endringene siden mennesket oppga sin tilværelse som jegere og sankere og ble bofaste, har vært i menneskets ernæring. Menneskets biokjemi og fysiologi er formet som resultat av flere millioner års evolusjon. Kostholdet har gjennom årtusener endret seg fra hovedsakelig å være basert på planter til - de siste 30-40.000 årene - å være dominert av kjøtt og fisk. Før jordbruksrevolusjonen startet for 10.000 år siden inntok mennesket signifikant mer energi enn moderne mennesker gjør. Maten hadde langt større næringstetthet, og karbohydratrike matvarer som korn og poteter inngikk ikke i menyen, langt mindre raffinert sukker, mel, iskrem og andre ferdigvarer. Fra et evolusjonsperspektiv er det åpenbart at mange av dagens matvaner ikke er tilpasset våre genetiske forutsetninger fordi de gir en alt for rask stigning i blodsukkeret etter et måltid.

Det er ingen nyhet at maten påvirker vår fysiske helse på kort og lang sikt. Kroniske lidelser som revmatisme, kreft, hjerte- og karsykdom, diabetes og andre autoimmunsykdommer skyldes i stor grad feilernæring. Mennesket er blant annet ikke konstruert for å innta store mengder raffinert mat Jegere og sankere har av og til funnet honning, som i ubearbeidet form inneholder både vitaminer, mineraler og ufordøyelige deler av bikuben. Raffinert mat har generelt lav næringstetthet og inneholder lite fiber, noe som er satt i sammenheng med en rekke sykdommer (Eaton, Shostak \& Konner 1988).

\section{Ernæring og antisosial atferd}

Det vi spiser, påvirker vår fysiske helse på kort og lang sikt. Mindre påaktet er at mangel på næringsstoffer kan utløse alvorlig psykisk ubalanse. Det er påvist at schizofrene pasienter får langt bedre prognose om de ble gitt store doser av Bvitaminet niacin (Osmond \& Smythies 1952, Hoffer \& Osmond 1957), vitamin C og sink (Hoffer 1998). Nobelprisvinner i kjemi og fred, dr. Linus Pauling, kunne senere gi en teoretisk forklaring for hvorfor næringskonsentrater kunne bidra til helbredelsen av mentale lidelser. Paulings hovedtese var at man ved å forsyne hjernen med optimale konsentrasjoner av stoffer som normalt er til stede i menneskekroppen, også vil kunne normalisere hjernens funksjoner (Pauling 1968 og 1974). Senere er det utført en rekke vitenskapelige undersøkelser som støtter hypotesen om at det er sammenheng mellom ernæringsstatus og antisosial atferd. Det er vist at et kosthold som inneholder mye sukker, ferdigmat og syntetiske tilsetningsstoffer, kan bidra til å utløse aggresjoner, hyperaktivitet og kriminalitet (Schoenthaler 1991). Allergiske reaksjoner på vanlige matvarer kan utløse såkalte hjerneallergier som kan føre til irrasjonell eller voldelig atferd.

På 1980-tallet ble det i amerikanske ungdomsfengsler og andre institusjoner foretatt en rekke undersøkelser som viste at forekomsten av antisosial atferd som vold, tyverier og hærverk ble betydelig lavere ved å gi de innsatte bedre kosthold - uten raffinert sukker, snacks og bearbeidede matvarer (Schoenthaler 
1991). Den største av disse undersøkelsene omfattet et utvalg på 3000 unge lovbrytere. En samlet undersøkelse foretatt ved California State University av 813 statlige ungdomsanstalter i 1991 viste at overgangen til "næringstette dietter" førte til "signifikant bedret atferd, intelligens og/eller skoleprestasjoner" (Schoenthaler, Moody \& Pankow 1991).

I 2002 ble resultatene av en randomisert, placebo-kontrollert studie om kosttilskudd til voksne fanger publisert (Gesch et al. 2002). Antisosial atferd i fengsler, inkludert vold, ble redusert ved tilskudd av vitaminer, mineraler og essensielle fettsyrer. Vi har derfor fått en første eksperimentell bekreftelse på det som først ble funnet ut for to tiår siden.

\section{Reaktiv hypoglykemi}

Sterkt bearbeidet ferdigmat er ofte fattig på næringsstoffer. Raffinering av sukker innebærer for eksempel at man fjerner alle B-vitaminene og krom, og hvitt mel med en utmalingsgrad på $70 \%$ har under halvparten av næringstettheten til helkorn. Krom er blant annet nødvendig for omdanningen av sukker, uten krom reduseres effektiviteten av kroppens insulin i å kontrollere blodets glukosenivå. Inntak av sukker eller matvarer som hvitt brød eller kaker, kan føre til såkalt "reaktiv hypoglykemi", dvs. at blodsukkeret først stiger raskt og så synker til under fastende verdi etter et måltid. Svingningene i blodsukkeret kan forverres ved mangel på viktige sporstoffer som krom og sink. Ved raskt blodsukkerfall kan hjernen få for lite glukose, noe som kan utløse aggressiv atferd, også hos normalt ikke-voldelige, friske personer i eksperimenter hvor man manipulerer deres blodsukkernivå ved hjelp av glukose eller insulin. Fordi det er omdiskutert hvilken betydning reaktiv hypoglykemi har for å utløse vold, er det også utført forsøk med mus som viser endret atferd under hypoglykemi.

En antropolog har undersøkt denne såkalte "hypoglykemi-aggresjonshypotesen" nærmere (Bolton 1984). Forskningen førte ham til qollastammen, som lever 3800 meter over havet ved Titicacasjøen i grenselandet mellom Bolivia og Peru. Qollastammen er i antropologisk litteratur blitt betegnet som "det mest brutale og usympatiske folkeslaget i verden" på grunn av sin antisosiale atferd. Drap, voldtekt, mordbrann og tyveri var vanlige foreteelser, og i én, spesiell landsby hadde mer enn halvparten av alle familieoverhoder direkte eller indirekte vært innblandet i drap. Seks uavhengige forskere som karakteriserte personlighetstrekk ved en gruppe qollaindianere, trakk fram uttrykk som "fiendtlig", "grusom", "intenst hat", "kranglete" og "hevngjerrige" (Bolton 1979). Da Bolton testet glukosetoleransen hos en gruppe voksne personer, fikk flere av dem så sterke symptomer på hypoglykemi (svetting, hodepine, svimmelhet) at testen ble avsluttet etter fire timer istedenfor de planlagte seks. Vel 55\% reagerte med reaktiv hypoglykemi, og det var klar sammenheng mellom rangert aggresjonsnivå og hypoglykemi under testen. Bolton hadde tidligere analysert sammenhengen mellom drap og en rekke variable i 34 afrikanske stammer og funnet 
at den mest sannsynlige utløsende faktoren, var graden av hypoglykemi pga. mangel på proteinrik mat (Bolton \& Vadheim 1973). Dette stemte godt med de funn han gjorde i qollastammen, hvor kostholdet var dominert av høyglykemiske, karbohydratrike matvarer (Food and Agricultural Organization/World Health Organization 1997) som poteter, supplert av bønner, erter, bygg, havre, søtpoteter og quinoa.

Amerikanske undersøkelser har vist at forekomsten av hypoglykemi blant voldelige kriminelle kan være så høy som $80-85 \%$ (Reed, Knickelbine \& Knickelbine 1983). Årsaken er at mange kriminelle har et kosthold dominert av matvarer med store mengder lett absorberbare karbohydrater, inkludert et høyt sukkerinntak. Slike matvarer kan virke passiviserende og føre til tretthet og depresjoner, samt virke søvndyssende (Budd 1981). Hypoglykemi er satt i sammenheng med selvmord, angst og panikkfølelse, mareritt, hyperaktivitet og alkoholisme, som igjen kan føre til mangel på viktige næringsstoffer som sink og tiamin (vitamin $\left.\mathrm{B}_{\bullet}\right)$. Siden hjernen trenger tiamin for å fungere normalt kan mangel på vitaminet igjen utløse aggressivitet, impulsive handlinger og gjøre at man blir mer ømfintlige overfor kritikk. En rekke kontrollerte fors $ø$ blant barn på sykehus har vist nær sammenheng mellom avvikende atferd og et næringsfattig kosthold. Også for mye kaffe eller alkohol kan utløse aggresjon, siden slike stoffer øker utskillelsen av flere mineraler (Schauss 1981a).

Det er påvist at rusmiddelavhengighet ofte er forbundet med dårlig ernæringsstatus. En norsk undersøkelse fra 1995 har vist at barn som fikk mye slikkerier og Cola hjemme, senere hadde lettere for å bruke alkohol og tobakk enn barn som ikke spiste mye slikkerier (Grimsmo, Storset \& Ødegaard 1995). Et næringsfattig kosthold kan igjen disponere for misbruk av narkotika, vold og kriminell atferd. Samtidig vet vi at rusmiddelmisbrukere står for en stor andel av samfunnets vold, grove ran og tyverier. Dyreforsøk har dessuten klart påvist at mangel på næringsstoffer som sink og tiamin kan utløse trang til alkohol og aggressiv atferd (Collipp et al. 1984, Kocken 1982). Uavhengig av psykososiale faktorer synes det å finnes klare forbindelser mellom feilernæring, alkoholisme, mentale lidelser og affektiv vold (Poleszynski 1984).

\section{Allergi og intoleranse mot mat}

Ungdom som utøver vold eller driver hærverk, lider ofte ikke bare av reaktiv hypoglykemi, de kan også ha allergier eller intoleranse mot bestemte matvarer (Jacobsen \& Vatn 1996, Helm \& Burks 2000). Allergiske reaksjoner innebærer immunreaksjoner mot proteiner som inntas i organismen via luft, vann eller mat. Det interessante i denne forbindelse er at spesielle matvarer både kan utløse kroppslige reaksjoner som tett nese, nysing, kløe eller utslett og psykologiske symptomer som angst, "panikkangrep", depresjoner, aggressiv atferd, irritabilitet, hyperaktivitet og visse former for autisme og schizofreni (Braly \& Torbet 1992, s. 45). En undersøkelse av matvanene hos en mindre gruppe ungdoms- 
kriminelle viste at den matvaren som i sterkest grad korrelerte positivt med antisosial atferd, var kumelk (Schauss 1981a, s. 14). Selv om nevnte undersøkelse ikke er representativ for normalbefolkningen, er det fra et evolusjonært perspektiv ikke overraskende at en stor andel av verdens befolkning ikke tåler melk og kan reagere både somatisk og psykisk ved jevnlig inntak (Oski 1983), siden kumelk er en relativt ny miljøfaktor i menneskets evolusjon (Eaton, Shostak \& Konner 1988).

Den amerikanske psykologen Alexander G. Schauss har også vist at allergi og matvareintoleranse kan være viktige årsaker når det gjelder å forklare hyperaktivitet, nervøsitet, lærevansker, depresjon, aggressiv atferd, fiendtlighet, forvirring og irritabilitet (Schauss 1981a, s. 75). Undersøkelser på 1970-tallet blant et utvalg på 133 psykiatriske pasienter fant at $74 \%$ led av reaktiv hypoglykemi (Reed, Knickelbine \& Knickelbine 1983, s. 58). Andre har påvist at lavt blodsukker forekommer hos omkring $70 \%$ av alle schizofrene. (Schizofreni er koblet til voldelig atferd, jf. Walsh, Buchanan \& Fahy 2002.) Ofte er også allergi mot vanlige matvarer involvert, jf den ovenfor siterte undersøkelsen om kumelk og kriminell atferd.

\section{Kolesterol, serotonin og vold}

Fra et evolusjonært ernæringsperspektiv er det interessant å merke seg at lave kolesterolnivåer i serum ser ut til å disponere for voldsatferd. Kolesterol påvirker nemlig serotoninnivået i hjernen, og serotonin er et viktig signalstoff som påvirker graden av impulskontroll. At lave serumnivåer av kolesterol kan gi lave serotoninnivåer i cerebrospinalvæsken med derav økt sannsynlighet for vold (samt impulsstyrte selvmord), omtales ofte som "kolesterol-serotonin-hypotesen" (for vold og aggresjon).

Kolesterol-serotonin-hypotesen anskueliggjør hvor viktig det er for medisinen å innta et evolusjonært perspektiv. Redusert matinntak med derav følgende lave kolesterolverdier kan antas å ha vært et tilbakevendende fenomen $i$ vår fortid. I perioder med lite mat kan det ha vært fordelaktig med en senket terskel for aggresjon (Erickson 1997). Mengden serumkolesterol fluktuerer til en viss grad med slike miljøforandringer og kan fysiologisk tenkes å medføre en varierende tilbøyelighet for aggresjon. Dette skjer via påvirkning på serotoninnivået. Kolesterol-serotonin-hypotesen består altså av tre ledd: 1) Nedsatt inntak av fettrik mat kan senke serumkolesterolnivået. 2) Dette kan igjen redusere serotoninnivået i sentralnervesystemet, noe som 3 ) igjen kan medføre økt tilbøyelighet til aggresivitet. Nivået av serumkolesterol kan historisk ha vært en pålitelig indre markør for tilgjengeligheten av mat med høy kvalitet (Erickson 1997). Det er ikke vanskelig å tenke seg at et aggressivt reaksjonsmønster kan ha vært adaptivt i menneskets evolusjonære fortid i tider med lite mat eller under direkte sultperioder. Når befolkninger i moderne vestlige land reduserer blodets kolesterolnivå (slanking har relativt liten effekt) medikamentelt, kan dette tenkes å utløse 
en latent tilbøyelighet til impulsiv, risikofylt og aggressiv atferd. Dette vil kunne forklare den økte dødsraten med voldelige dødsårsaker som er observert i forskning der en nedsetter kolesterolnivået.

\section{Tungmetallforgiftning}

I USA har forskere foretatt en rekke ernæringsstudier av drapsmenn og andre lovbrytere. Et fellestrekk ved siden av dårlig kosthold er at mange har vært utsatt for forgiftninger med tungmetaller. Flere tungmetaller som kadmium, bly, kobber og mangan er satt i sammenheng med affektiv vold (Masters, Hone \& Doshi 1998, Schauss 1981a, Schauss 1981b). For å teste denne hypotesen foretok en gruppe ved University of Texas i 1989 en analyse av sporelementer i håret til et utvalg på 80 fanger (Cromwell et al. 1989). Utelukkende på bakgrunn av forekomsten av tungmetaller i hårprøvene klarte de å klassifisere $86 \%$ av de voldelige og $78 \%$ av de ikke-voldelige fangene. Senere studier har klargjort at håranalyser av voldsforbrytere ofte viser påfallende høye verdier av tungmetaller.

Mengden mangan i håret har vist seg å være en god indikator på voldsatferd. Bly og mangan ser nemlig ut til henholdsvis å kunne senke nivåer av dopamin og serotonin i hjernen - signalstoffer som påvirker impulskontroll (Masters, Hone \& Doshi 1998) (jf. diskusjonen av serotonin). Ved fire amerikanske fengsler undersøkte man hvor mange innsatte som hadde unormal høy konsentrasjon av mangan i hårprøven. Blant fangene fant man at dette gjaldt for henholdsvis $66 \%$ (to storbyfengsler), $78 \%$ (statsfengsel) og 63\% (fylkesfengsel), mot $4 \%$, $3 \%$ og 3\% blant kontrollene (Alex G. Schauss, personlig meddelelse).

Håranalyser foretatt av flere av USAs kjente massemordere har avslørt at flere av dem hadde forhøyede mengder av tungmetaller i kroppen (dette gjelder faktisk tilfeller der en rekke psykososiale faktorer tilsynelatende kan sjaltes ut). Et hyppig sitert eksempel er undersøkelsene av massemorderen Patrick H. Sherill, som 20. august 1986 gikk berserk på et postkontor i Oklahoma og drepte 14 personer, såret seks andre og så tok sitt eget liv. Sherill hadde ingen tidligere psykiatrisk lidelse eller alkoholisme. Derimot viste håranalyser at han hadde ekstremt høye verdier av kadmium og bly (Hall 1989). Et annet eksempel er massemorderen James Huberty, som i 1984 drepte og skadde 20 personer på en McDonald's-restaurant i California. Han ble drept av politiet etterpå. Heller ikke Huberty led av alkoholisme eller brukte spesielle medikamenter. Derimot hadde han ekstremt høye kadmiumnivåer i kroppen, faktisk blant de høyeste som var observert hos noe menneske. Huberty var blitt eksponert mens han arbeidet som sveiser (Hall 1989).

I 1996 ble det påvist at et utvalg på 301 gutter ved offentlige skoler var mer tilbøyelig til antisosial atferd, dersom de hadde mer bly i bensubstansen (Needleman et al. 1996). Senere undersøkelser av 216 kriminelle ungdommer og 201 elever fra videregående skoler i Pittsburgh viste at de kriminelle hadde signifi- 
kant mer bly i bensubstansen enn kontrollene (Needleman et al. 2000). En undersøkelse av samtlige fylker i 48 stater i USA fant klare assosiasjoner mellom drapsraten og luftens innhold av bly (Stretesky \& Lynch 2001), og en britisk studie påviste en sammenheng mellom blynivået i blodet og atferds- og/eller utviklingsproblemer hos barn som ikke kunne forklares av forskjeller i alder, kjønn eller sosioøkonomisk status (Lewendon et al. 2001).

Resultatene gjengitt ovenfor styrkes av en forskergruppe som ved hjelp av håranalyser undersøkte forekomsten av seks giftige sporelementer og 14 andre mineraler hos et utvalg på 31 mentalt forstyrrede gutter, 21 voldelige og 99 kontroller (Marlowe, Bliss \& Schneider 1994). Forskerne fant positiv sammenheng mellom voldelig atferd og økt innhold av kadmium, bly, kopper, mangan, jern, nikkel og kadmium og redusert nivå av fosfor, samt mellom mentale forstyrrelser og økt innhold av mangan og redusert nivå av fosfor. I en annen undersøkelse av barn påviste den samme forskergruppen ved hjelp av håranalyser at det var positiv sammenheng mellom tilbøyelighet til voldsatferd og nivået av bly, kadmium, kobber, jern og silisium og negativ sammenheng med nivået av litium. Også forekomsten av mentale forstyrrelser økte med nivået av bly og kadmium og sank med nivået av fosfor (Marlowe, Schneider \& Bliss 1991). Disse resultatene indikerer at det kan finnes biokjemiske forskjeller mellom normale, mentalt forstyrrede og voldstilbøyelige barn.

Flere andre studier har påvist koblinger mellom tungmetallpåvirkning og voldsatferd. Her foreligger det etter vår oppfatning med stor sannsynlighet kausale koblinger, siden tungmetaller som nevnt kan senke nivåer av signalstoffer som har med impulskontroll å gjøre. Selv om omfattende forskning er i gang for å klarlegge dette nærmere, er slike problemstillinger så krevende å avdekke at noen avgjørende vitenskapelig avklaring ikke kan forventes i overskuelig framtid.

\section{Samvirke av miljøfaktorer}

Vi skal merke oss at om maten inneholder for lite inntak av essensielle næringsstoffer, kan man få et økt opptak i tarmen av bly, mangan og andre giftstoffer fra drikkevann eller matvarer med påfølgende opptak av slike stoffer i hjernen. For eksempel er det holdepunkter for at fluoridering av drikkevann med lettløselige fluorforbindelser kan bidra til økt voldsbruk. Dette skyldes bruken av to fluorforbindelser som har vist seg å øke opptaket av bly fra kilder i miljøet til organismen. Mer enn $90 \%$ av den vannfluorideringen som finner sted i USA, skjer med disse to fluorforbindelsene fordi de er langt billigere enn natriumfluorid.

Det er vist at laboratoriedyr med et kosthold som inneholdt mye mangan, ikke absorberte det, mens manganopptaket økte signifikant når maten manglet kalsium (Murphy et al. 1991). Hos mennesket kan slike effekter være koblet til sosial klasse/lagdeling. Folk lavt på den sosiale rangstigen har oftere et dårligere sammensatt kosthold enn de høyere oppe. Forskning tyder ikke uventet på at 


\section{NORDISK TIDSSKRIFT FOR \\ KRIMINALVIDENSKAB}

\section{REDAKTION}

RAGNHEIDUR BRAGADÓtTIR

Professor, cand. jur.

Reykjavik

HANNS VON HOFER

Professor, jur. dr.

Stockholm

Kimmo Nuotio

Professor, jur. dr.

Helsingfors
KJERsti ERICSSON

Professor, cand. psychol.

Oslo

BRITTA KYVSGAARD

Forskningschef, dr. jur.

Hovedredaktør

København

Per Ole Träskman

Professor, jur. dr.

Lund

HILDIGUNNUR ÓLAFSDOTTIR Forsker, dr. philos.

Reykjavik 
Nordisk Tidsskrift for Kriminalvidenskab er trykt af KANDRUPS BOGTRYKKERI Århusgade 88, DK-2100 København Ø ISSN 0029-1528 


\section{INDHOLD}

ARTIKLER Side

Yngve Carlsson: 'Forebyggingskjøkkenet': Velferdskommunens problem

- ekspansjon og den internasjonale 'programindustrien' - konsekvenser

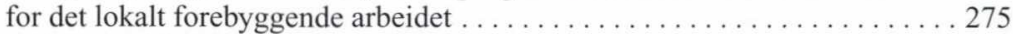

Susanne Clausen: Terrorangrebet på USA og bekymring for kriminalitet $\ldots \ldots \ldots 16$

Thomas Elholm: Den Europæiske Unions harmonisering af strafferetten . . . . . . . 77

Morten Eriksen: Politivoldsakene i Bergen - status etter 19 år med dyp uenighet . . 36

Birgit Feldtmann: Anklagemyndighedens rolle - nogle komparative tanker om

legalitet $\mathrm{og}$ opportunitet $\mathrm{i}$ det danske $\mathrm{og}$ det tyske retssystem . . . . . . . . 157

Inga Floto: Dødsstraffens former: Fra ritual til procedure . . . . . . . . . . . 259

Peter Garde: Bevis og bevisbedømmelse med særlig henblik på sager om

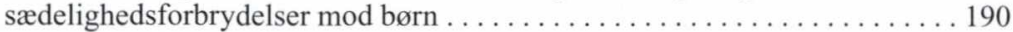

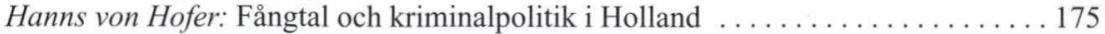

Britta Kyvsgaard: Kan forbrydelser forudsiges? - Om strategiske forbrydelser . . . . 27

Lars Lidberg: Ätten Bernadotte och svensk kriminalvård . . . . . . . . . . . . . . 208

Henrik Linderborg: Samhällstjänsten som ett självdisciplinerande straff . . . . . . 106

Sakari Melander: Kriminaliseringsprinciper och förutsättningar för begränsning

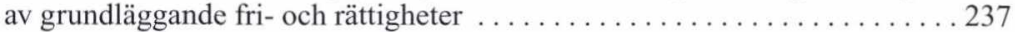

Mette Irmgard Snertingdal: Kjøpesentervakthold: Privatisering av kontroll? . . . . . 127

Per Ole Träskmann: Straffrättens förutsättningar och begränsningar som

styrmedel av miljöskadlig verksamhet $\ldots \ldots \ldots \ldots \ldots \ldots \ldots \ldots \ldots$

\section{KRONIKKER}

Norsk kronikk 1999-2001 av Paul Larsson, Ragnhild Hennum och Asbjørn

Strandbakken .....................................55

KOMMENTAR

Politivoldsaken i Bergen - en sak med bare tapere av Anders Bratholm . . . . . . . 136

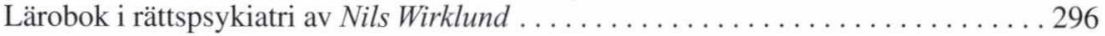

\section{BOGANMELDELSER}

Hans Henrik Brydensholt af ALBIN ESER, MICHAEL FIBERHOFEN \&

BARBARA HUBER: Korruptionsbekämpfung durch Strafrecht . . . . . . . 59

René Dejbjerg Pedersen af MICHAEL ELLEHAUGE: Inhabilitet i dansk retspleje 227

Thomas Elholm af R. A. DUFF: Punishment, Communication and Community . . . 302

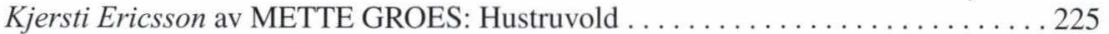

Felipe Estrada av FLEMMING BALVIG: Det voldsomme samfund . . . . . . 153

Janne Flyghed av DAVID KAUZLARICH \& RONALD C. KRAMER:

Crimes of the American Nuclear State . . . . . . . . . . . . . 311

Peter Garde af ALBIN ESER \& JÖRG ARNOLD: Strafrecht in Reaktion auf

Systemunrecht . . . . . . . . . . . . . . . . . . . . . . . 140

--- $\quad$ af KEN ECKSTEIN: Besitz als Straftat $\ldots \ldots \ldots \ldots \ldots \ldots \ldots \ldots \ldots \ldots \ldots \ldots$

--- af JAN WILLEM DE KEIJSER: Punishment and Purpose . . . . . . . . . . 223 
--- $\quad$ af CHRISTIAN DIESEN, CLARA HELLNER GUMPERT, FRANK LINDBLAD \& HELENA SUTORIUS: Bevis 6 - Sexuella övergrepp mot barn . . . . . . . . . . . . . . . . . . . . . . . . . . . . 297

Hedda Giertsen av INGRID SAHLIN: Brottsprevention som begrepp och samhällsfenomen .............................67 67

Ragnhild Hennun av OLE BRINK: Voldtægtsofre. Håndbog for fagpersoner . . . . . . 70 Sverker Jönsson av ALBIN ESER, GÜNTER HEINE \& BARBARA HUBER:

Criminal Responsibility of Legal and Collective Entities . . . . . . . . . . 60 Maria Kaspersson av INGA FLOTO: Dødsstraffens kulturhistorie . . . . . . . . . . 212

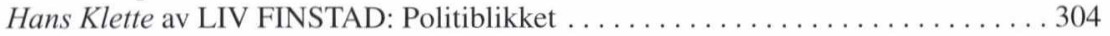

--- av BEN EMMERSON \& ANDREW ASHWORTH: Human Rights and Criminal Justice . . . . . . . . . . . . . . . . . . . . . . . . . . . . 313

Peter Kramp af LARS LIDBERG: Svensk rättspsykiatri - en handbok . . . . . . . . 216 Peter Kruize af MALCOLM W. KLEIN, HANS-JÜRGEN KERNER, CHERYL L. MAXSON \& ELMAR G. M. WEITEKAMP:

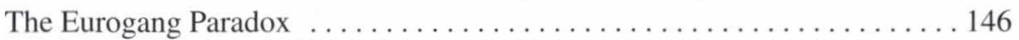

--- af TORE BJøRGO, YNGVE CARLSSON \& THOMAS HAALAND:

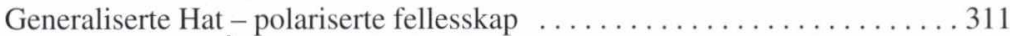

Lars Bo Langsted af BRÅ: Från storsvindel till småfiffel . . . . . . . . . . . . . . . 222

--- af BENGT LARSSON: Bankkrisen, medierna och politiken . . . . . . . . 301

Paul Larsson av RICHARD QUINNEY: Bearing Witness to Crime and Social

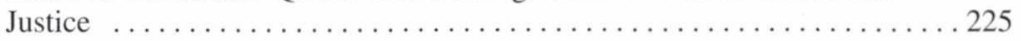

--- av DEAN J. CHAMPION: Probation, Parole, and Community

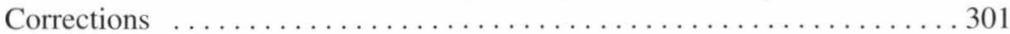

Charlotte Mathiesen Bech af LISA L. MILLER: The Politics of Community

Crime Prevention . . . . . . . . . . . . . . . . . . . . . . . . . . 213

af ANDERS BRATHOLM: Mobbing og feighet . . . . . . . . . . . . . . 299

Rachel Paul \& Ragnhild Hennum av ELIZABETH M. SCHNEIDER:

Battered Women and Feminist Lawmaking . . . . . . . . . . . . . . 144

Bettina Schütz-Gärdén av HANS KUDLICH: Strafprozess und allgemeines

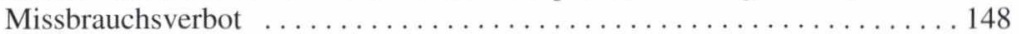

Anette Storgaard af JUSS-BUSS: Tvers igjennom lov til seier . . . . . . . . . 152

Henrik Tham av DAVID GARLAND \& RICHARD SPARKS:

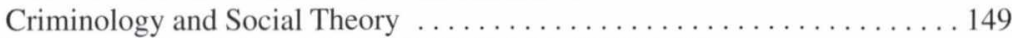

Stig Winge av GORDON HUGHES, EUGENE McLAUGHLIN

\& JOHN MUNCIE: Crime Prevention and Community Safety . . . . . . . 226

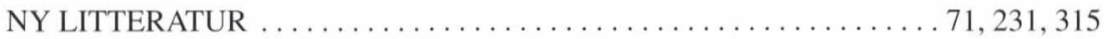


amerikanske minoritetsbarn med lavt kalsiuminntak har økt risiko for opptak av bly (Bruening et al. 1999). Siden kvinner fra lavere sosiale lag har en en tendens til lavere ammefrekvens eller å amme kortere enn de fra høyere sosiale lag, får barn i lavere sosiale lag i seg mer mangan. Barn som gis morsmelkerstatning, får i seg fem ganger mer mangan enn de som ammes (Masters, Grelotti, Hone, Gonzalez \& Jones 1997). Lavstatusbarn har større sannsynlighet for å innta giftstoffer fordi de oftere enn høystatusbarn lever i miljøer med stor industriforurensning, i storbyer, samt får drikkevannet fra gamle vannrør belagt med bly og bor i hus som inneholder maling med blytilsetning.

Et interessant mineral som settes i forbindelse med atferdsforstyrrelser og vold, er litium. I en kontrollert undersøkelse av fanger med en forhistorie preget av kronisk, impulsiv og aggressiv vold fikk en gruppe litium $(n=34)$ og en annen placebo $(n=32)$ i en periode på inntil tre måneder. Litiumgruppen viste signifikant mindre aggressiv atferd enn placebogruppen (Sheard et al. 1976). En annen studie fra 27 kommuner i Texas påviste høyere forekomst av selvmord, drap og voldtekt i de kommunene der drikkevannet inneholdt lite eller intet litium enn der det inneholdt en viss mengde av dette stoffet. Liknende sammenheng ble også funnet for ran, innbrudd og tyveri (Schrauzer \& Shrestha 1990). At litium i lave doser generelt har fordelaktige effekter på menneskets atferd, kan trolig forklares med at litium er et essensielt sporelement.

Eksponering for giftstoffer, dårlig kosthold og stoffmisbruk kan ha synergistiske effekter på hjernens funksjon og sosial atferd, jf. Bryce-Smith 1986:

Endret hjernekjemi kan forandre atferd, og endret atferd kan forandre hjernekjemi: interaksjonen går begge veier. Av dette følger derfor at atferd, kognisjon og sosiale interaksjoner $\mathrm{og}$ andre uttrykk for hjernefunksjon ikke bare eksponeres for det sosiale miljøet, men også for spesifikke aspekter ved det kjemiske miljøet. (s. 122, vår oversettelse).

Undersøkelser har påvist at atomanlegg og atomsprengninger over bakken gir radioaktiv forurensning som direkte (via luft) og indirekte (via næringskjeden) kan ramme store deler av befolkningen og gi økende kreftrater, redusert fødselsvekt og svekket immunitet i nedfallsområdene (Gould 1996). Radioaktive isotoper som jod-131 påvirker dessuten hjernen negativt og virker synergistisk med andre giftstoffer. Amerikanske overjordiske atomprøvesprengninger på 1950- og 60-tallet førte til massive utslipp. Nedfall av jod-131 absorberes via næringskjeden, og gravide som drikker melk, vil overføre jod-131 til fosteret, noe som kan hemme barnets produksjon av skjoldkjertelhormoner og dermed hjernens utvikling. Der er påvist entydig negativ korrelasjon mellom mengden radioaktivt nedfall da moren var gravid og resultater av skoletester hos de samme ungdommene i videregående skole (Anonymous 1979, Sternglass \& Bell 1983, Sternglass \& Bell 1984). Der er videre påvist at det var statistisk sammenheng mellom radioaktivt nedfall og voldsforbrytelser i USA (Pellegrini 1987, Graeb 1994, s. 169). 


\section{Veien framover}

Hovedtyngden av forskere med bakgrunn i "samfunnsvitenskapenes standardmodell" har lenge oversett biokjemiske forklaringsfaktorer på voldsbruk. Faktisk har det blant kriminologer på nesten hele 1900-tallet nærmest vært tabu å nevne biologiske argumenter som kobler biokjemi, genetikk og/eller nevrofysiologi til kriminell atferd. Lærebøker reflekterer tidsånden i de enkelte fagene, og kriminologiske lærebøkers manglende dekning av biologiske argumenter vitner om total dominans av psykososiale variable. Dette er imidlertid i ferd med å endre seg (Wright \& Miller 1998), og det finnes ett godt unntak blant lærebøker i kriminologi som vier plass til et bredt spekter av psykososiale og "biologiske" forklaringsvariable og teorier (Ellis \& Walsh 2000). Selv om den evolusjonspsykologiske modellen forkaster dette skillet mellom psykososialt og "biologisk" som unaturlig, har evolusjonsforskerne til nå ikke vært nok oppmerksomme på hvordan en rekke evolusjonært sett nye miljøfaktorer kan påvirke hjernekjemien og utløse eller øke sannsynligheten for voldelig atferd. Dette er imidlertid nå $\mathrm{i}$ svak endring (Masters, Hone \& Doshi 1998). I årene som kommer vil det være en stor utfordring for forskere innenfor forskjellige tradisjoner å integrere nyere forskning til mer realistiske modeller for atferd enn de som finnes i dag.

Forståelsen av hvordan de miljøfaktorene vi har presentert i denne artikkelen påvirker atferd, er på ingen måte god nok i dag. Noe av den presenterte forskningen er omstridt, og dette peker på det sedvanlige ropet på mer forskning. Etter vår oppfatning vet vi likevel nok om en del av disse sammenhengene til å rope varsko her! Dette gjelder for eksempel betydningen av bly som årsaksfaktor for å forklare voldelig og antisosial atferd. At dette er brennaktuelle sosiale temaer, skulle være klart. I USA raste det i 1994 en opphetet debatt rundt boka The Bell Curve (Herrnstein \& Murray 1994), hvor spørsmålet var hvorvidt det var slik at afroamerikanere ("de svarte") var mer voldelige og hadde lavere intelligens på grunn av genetiske faktorer enn folk av europeisk herkomst ("de hvite"). Nå har forskere som ser på koblingen mellom eksponering for tungmetaller, ernæringsstatus og sosiale levekår, påpekt at slike sammenfall av faktorer blant annet ser ut til å skyldes blyforgiftning hos mennesker som lever under dårlige levekår (Masters, Grelotti, Hone, Gonzalez \& Jones 1997). Fattige afroamerikanere er ofte sterkt eksponert for forurensninger og har generelt et næringsfattig kosthold. Slike momenter er selvfølgelig av betydning ved studier av nye miljøfaktorer som kan bidra til at vår forståelse av vold og aggresjon hos mennesket blir vesentlig bedre enn om vi utelukkende baserer oss på samfunnsvitenskapenes standardmodell med ensidig fokus på psykososiale miljøfaktorer. Et fokus på nye miljøfaktorer vil også kunne bringe evolusjonspsykologiens forståelse av mennesket mange hakk framover. I tillegg vil slik forskning kunne avklare en del av de opphetede debattene av typen som raste rundt The Bell Cur$v e$. Med den interessen det er både blant folk flest og forskere for temaet vold, aggresjon og antisosial atferd, er det påfallende at slike perspektiver i liten grad 
reflekteres i massemediene og i mange forskeres analyser. Vi mener det nå er på høy tid å stikke fingeren i jorda og komme fram til bedre strategier for å løse voldsproblemene i vestlige industrisamfunn, både med strukturelle tiltak og med tiltak på individnivå. Har vi råd til å ignorere det bidraget nye miljøfaktorer ser ut til å spille i dagens samfunn?

\section{LITTERATUR}

Vi har i denne artikkelen fjernet en rekke referanser. De som ønsker å gå dypere inn i disse emnene henvises til tre av våre andre publikasjoner (Mysterud 2003, Mysterud \& Poleszynski 2003, Poleszynski \& Mysterud 2003).

Anonymous 1979. The nuclear radiation/SAT decline connection. Phi Delta Kappan (November): 184-187.

Bolton, Ralph 1979. Differential aggressiveness and litigiousness: Social support and social status hypotheses. Aggressive Behavior 5: 233-255.

Bolton, Ralph 1984. The hypoglycemia-aggression hypothesis: Debate versus research. Current Anthropology 25: 1-53.

Bolton, Ralph og Constance Vadheim 1973. The ecology of East African homicide. Behavior Science Notes 8: 319-342.

Braly, James og Laura Torbet 1992. Dr. Braly's food allergy and nutrition revolution: For permanent weight loss and a longer, healthier life. New Canaan, CT: Keats Publishing.

Bruening, K., F. W. Kemp, N. Simone, Y. Holding, D. B. Louria og J. D. Bogden 1999. Dietary calcium intakes of urban children at risk of lead poisoning. Environmental Health Perspectives 107: 431-435.

Bryce-Smith, Derek 1986. Environmental chemical influences on behaviour and mentation. Chemical Society Reviews 15: 93-123.

Budd, Martin L. 1981. Low blood sugar (hypoglycaemia). The 20th century epidemic? Wellingborough, Northamptonshire: Thorsons Publishers Limited.

Buss, David M. 1995. Evolutionary psychology: A new paradigm for psychological science. Psychological Inquiry 6: 1-30.

Buss, David M. og Todd K. Shackelford 1997. Human aggression in evolutionary psychological perspective. Clinical Psychology Review 17: 605-619.

Collipp, P. J., V. K. Kris, M. Castro-Magana, A. Shih, S. Y. Chen, N Antoszyk, J. Baltzell, J. Noll og C Trusty 1984. The effects of dietary zink deficiency on voluntary alcohol drinking in rats. Alcoholism: Clinical and Experimental Research 6: 556-559.

Cromwell, P. F., B. R. Abadie, J. T. Stephens og M. Kyler 1989. Hair mineral analysis: Biochemical imbalances and violent criminal behavior. Psychological Reports 64: 259-266.

Daly, Martin og Margo Wilson 1988. Homicide. New York: Aldine de Gruyter.

Daly, Martin og Margo Wilson 1994. "Evolutionary psychology of male violence". I J. Archer (red.): Male violence. pp. 253-288. London \& New York: Routledge.

Eaton, Stanley Boyd, Marjorie Shostak og Melvin Konner 1988. The Paleolithic prescription: A program of diet \& exercise and a design for living. New York: Harper \& Row.

Ellis, Lee og Anthony Walsh 2000. Criminology: A global approach. Boston: Allyn \& Bacon.

Erickson, Mark T. 1997. Lowered serum cholesterol, famine and aggression: a Darwinian hypothesis. Social Science Information 36: 211-222.

Food and Agricultural Organization/World Health Organization 1997. Carbohydrates in human nutrition. Report of a joint FAO/WHO expert consultation. Rome: 
Gesch, C. Bernard, Sean M. Hammond, Sarah E. Hampson, Anita Aves og Martin J. Crowder 2002. Influence of supplementary vitamins, minerals and essential fatty acids on the antisocial behaviour of young adult prisoners: Randomized, placebo-controlled trial. British Journal of Psychiatry 181: 22-28.

Glenmullen, Joseph 2000. Prozac Backlash. New York: Simon \& Schuster.

Gould, Jay M. 1996. The enemy within. The hight cost of living near nuclear reactors. New York: Four Walls Eight Windows.

Graeb, Ralph 1994. The Petkau effect. The devastating effect of nuclear radiation on human health and the environment. New York: Four Wals Eight Windows.

Grimsmo, Anders, Bjarne Storset og Jan Arne Ødegaard 1995. Utvikling av alkoholvaner blant ungdom. Faktorer som har sammenheng med alkoholkonsumet. Tidsskr Nor Lageforen 115: 27642767.

Hall, Robert W. 1989. A study of a mass murder: Evidence of underlying cadmium and lead poisoning and brain involved immunoreactivity. International Journal of Biosocial and Medical Research 11: 144-152.

Helm, Ricki M. og A. Wesley Burks 2000. Mechanisms of food allergy. Current Opinion in Immunology 12: 647-653.

Herrnstein, Richard J. og Charles Murray 1994. The bell curve: Intelligence and class structure in American life. New York: Free Press.

Hoffer, Abram 1998. Vitamin B-3. Schizophrenia. Discovery, recovery, controversy. Kingston, Ontario, Canada: Quarry Press.

Hoffer, Abram og H. Osmond 1957. Treatment of schizophrenia with nicotinic acid and nicotinamide. Journal of Clinical and Experimental Psychopathology 18: 131-158.

Jacobsen, M. B. og M. H. Vatn 1996. Syk av mat? Kunnskaper og hypoteser om matvareintoleranse. Nordisk Medicin 111 (4): 109-112.

Kocken, Anders 1982. Kostvanor och alkohol. Några vegetariska vetenskapligt styrkta aspekter. Hälsonytt vegetarianen (1-2): 17-27.

Lewendon, G., S. Kinra, R. Nelder og T. Cronin 2001. Should children with developmental and behavioural problems be routinely screened for lead? Archives of Disease in Childhood 85: 286-288.

Linnoila, Markku et al. 1994. "Serotonin and violent behavior". I M.T. McGuire (red.): The neurotransmitter revolution: Serotonin, social behavior, and the law. pp. 61-95. Carbondale \& Edwardsville: Southern Illinois University Press.

Marlowe, Mike, Leonard Bliss og Henry G. Schneider 1994. Hair trace element content of violence prone male children. Journal of Advancement in Medicine 7: 5-18.

Marlowe, Mike, H. G. Schneider og L. B. Bliss 1991. Hair mineral analysis in emotionally disturbed and violence prone children. International Journal of Biosocial and Medical Research 13: 169179.

Masters, Roger D., David J. Grelotti, Brian T. Hone, David Gonzalez og David Jones 1997. "Brain biochemistry and social status: The neurotoxicity hypothesis". I E. White (red.): Intelligence, political inequality, and public policy. pp. 141-183. Westport, CT \& London: Praeger.

Masters, Roger D., B. Hone og A. Doshi 1998. "Environmental pollution, neurotoxicity, and criminal violence". I J. Rose (red.): Environmental toxicology: Current developments. pp. 13-48. Amsterdam: Gordon and Breach Science Publishers.

Masters, Roger D. og Michael T. McGuire (red.) 1994. The neurotransmitter revolution: Serotonin, social behavior, and the law. Carbondale \& Edwardsville: Soutern Illionois University Press.

Murphy, Vincent A., J. M. Rosenberg, Quentin R. Smith og Stanley I. Rapoport 1991. Elevation of brain manganese in calcium-deficient rats. NeuroToxicology 12: 255-264.

Mysterud, Iver 2003. Mennesket og moderne evolusjonsteori. Oslo: Gyldendal Akademisk.

Mysterud, Iver and Poleszynski, Dag Viljen 2003. Expanding evolutionary psychology: Violence as a case. Social Science Information 23: 5-50. 
Needleman, Herbert L., Christine McFarland, Roberta Ness, Michael Tobin og Joel Greenhouse 2000. Bone lead levels in adjudicated delinquents: a case-control study. Pediatric Research 47: $155 \mathrm{~A}-155 \mathrm{~A}$.

Needleman, Herbert L., Julie A. Riess, Michael J. Tobin, Gretchen E. Biesecker og Joel B. Greenhouse 1996. Bone lead levels and delinquent behavior. JAMA 275: 363-369.

Oski, Frank A. 1983. Don't drink that milk! The frightening facts about the world's most overrated nutrient. Syracuse, NY: Mollica Press.

Osmond, H. og J. Smythies 1952. Schizophrenia: a new approach. Journal of Mental Science 98: 309-315.

Pauling, Linus 1968. Orthomolecular psychiatry. Science 160: 265-271.

Pauling, Linus 1974. On the orthomolecular environment of the mind: Orthomolecular theory. American Journal of Psychiatry 131: 1251-1257.

Pellegrini, R. J. 1987. Nuclear fallout and criminal violence: preliminary inquiry into a new, biogenic predisposition hypothesis. International Journal of Biosocial Research 9: 125-143.

Pinker, Steven 1997. How the mind works. New York: Norton.

Poleszynski, Dag 1984. Food, social cosmology and mental health: The case of refined sugar (sucrose). The International Journal For Biosocial Research 6: 175-213.

Poleszynski, Dag Viljen and Mysterud, Iver 2003. Vold, evolusjon og hjernekjemi. Nordisk Tidsskrift for Biologisk Medisin (i trykk).

Raleigh, Michael J. og Michael T. McGuire 1994. "Serotonin, aggression, and violence in vervet monkeys". I M.T. McGuire (red.): The neurotransmitter revolution: Serotonin, social behavior, and the law. pp. 129-145. Carbondale \& Edwardsville: Southern Illinois University Press.

Reed, B., S. Knickelbine og M. Knickelbine 1983. Food, teens \& behavior. Manitowoc, WI: Natural Press.

Schauss, Alexander 1981. Diet, crime and delinquency. Berkeley, CA: Parker House.

Schauss, Alexander G. 1981. Comparative hair-mineral analysis results of 21 elements in a random selected behaviorally 'normal' 19-59 year old population and violent adult criminal offenders. International Journal of Biosocial Research 1:21-41.

Schoenthaler, Stephen J. 1991. Improve your child's IQ and behavior. London: BBC Books.

Schoenthaler, Stephen J., Jeannie M. Moody og Lisa D. Pankow 1991. Applied nutrition and behavior. Journal of Applied Nutrition 43: 31-39.

Schrauzer, Gerhard N. og Krishna P. Shrestha 1990. Lithium in drinking water and the incidences of crime, suicides, and arrests related to drug addictions. Biological Trace Element Research 25: 105-113.

Sheard, Michael H., James L. Marini, Carolyn I. Bridges og Ernest Wagner 1976. The effect of lithium on impulsive aggressive behavior in man. American Journal of Psychiatry 133: 1409-1413.

Stein, Dan J. og Michael Stanley 1994. "Serotonin and suicide". I M.T. McGuire (red.): The neurotransmitter revolution: Serotonin, social behavior, and the law. pp. 47-60. Carbondale \& Edwardsville: Southern Illinois University Press.

Sternglass, Ernest J. og Steven Bell 1983. Fallout and SAT scores: evidence for cognitive damage during early infancy. Phi Delta Kappan (April): 539-545.

Sternglass, Ernest J. og Steven Bell 1984. The 1983 SAT scores and their link to nuclear fallout. Phi Delta Kappan (January): 372-373.

Stretesky, Paul B. og Michael J. Lynch 2001. The relationship between lead exposure and homicide. Archives of Pediatric and Adolescent Medicine 155: 579-582.

Tooby, John og Leda Cosmides 1992. "The psychological foundations of culture". I J.H. Barkow, L. Cosmides, \& J. Tooby (red.): The adapted mind: Evolutionary psychology and the generation of culture. pp. 19-136. New York: Oxford University Press.

Walsh, Elizabeth, Alec Buchanan og Thomas Fahy 2002. Violence and schizophrenia: examining the evidence. British Journal of Psychiatry 180: 490-495. 
Wilson, David Sloan 1994. Adaptive genetic variation and human evolutionary psychology. Ethology and Sociobiology 15: 219-235.

Wright, R. A. og J. M. Miller 1998. Taboo until today? The coverage of biological arguments in criminology textbooks, 1961 to 1970 and 1987 to 1996. Journal of Criminal Justice 26: 1-19.

Adresse:Iver Mysterud

Biologisk institutt

Universitetet i Oslo

$\mathrm{Pb} .1050$ Blindern

NO - 0316 Oslo

Tlf 228581 92. Faks 228546 05. E-post mysterud@bio.uio.no 